[Radiogarbon, Vol. 12, No. 2, 1970, P. 617-639]

\title{
UNIVERSITY OF TEXAS AT AUSTIN RADIOCARBON DATES VIII
}

\author{
S. VALASTRO, JR. and E. MOTT DAVIS \\ Radiocarbon Laboratory, Balcones Research Center, \\ The University of Texas at Austin
}

This list reports $\mathrm{C}^{14}$ measurements made in projects completed in the year ending October, 1969, and some measurements for projects still in progress. Age calculations are based on $\mathrm{C}^{14}$ half-life of 5568 years and a modern standard of $95 \%$ of NBS oxalic acid. Deviations reported are based on counting statistics of sample, background, and modern, and are $\pm 1 \sigma$ except that when sample count approaches either modern or background, $2 \sigma$ limits are reported. The laboratory uses liquid scintillation counting of benzene, with $\mathrm{Li}_{2} \mathrm{C}_{2}$ and vanadium activated catalyst in preparation. Chemical yields average $88 \%$.

Valastro is in charge of technical operations in the laboratory; he and Davis share administrative responsibilities. Davis handles sample screening and archaeologic appraisal, and has compiled this list.

\section{ACKNOWLEDGMENTS}

We acknowledge with gratitude the work of Alejandra G. Varela and Anibal Silvestri in the preparation of samples, and the secretarial assistance of Fernanda Keeler and Julia Reaves.

\section{CHECK SAMPLE}

In addition to sample below, see Tx-680, in Archaeologic Samples.

\section{Tx-693. Danvers, Illinois}

$23,880 \pm 490$

Wood chips from bed of woody peat, $1.4 \mathrm{~m}$ below top of Farmdale silt, $3 \mathrm{mi} \mathrm{SW}$ of Congerville, $5 \mathrm{mi} \mathrm{NW}$ of Danvers, Illinois $\left(40^{\circ} 35^{\prime} 12^{\prime \prime}\right.$ N Lat, $89^{\circ} 14^{\prime} 40^{\prime \prime} \mathrm{W}$ Long). Sample was split and the 2 parts prepared and counted separately: 23,520 $\pm 640,24,230 \pm 750$. Another part of same sample dated as ISGS-12, 23,900 \pm 200 (Kim, pers. commun.). Subm. by S. M. Kim, Ill. State Geol. Surv., Urbana. Comment: excellent agreement.

\section{OCEANOGRAPHIC SAMPLES}

\section{A. South Gulf Coast, Texas}

\section{Padre Island Beach series, Texas}

Shells (Mercenaria mercenaria) from back shore surface, beach of Padre I., $1 / 4 \mathrm{mi} \mathrm{N}$ of Mansfield Pass channel $\left(26^{\circ} 34^{\prime} \mathrm{N}\right.$ Lat, $97^{\circ} 17^{\prime}$ W Long). Shells represent large source of beach material. Source area seems to be offshore Gulf of Mexico. Dated to see whether such an unlikely habitat for this species has existed recently or if shells represent reworking of Pleistocene deposits outcropping offshore. Coll. 1968 by Behrens and Frishman; subm. by E. W. Behrens, Univ. of Texas Marine Sci. Inst., Port Aransas, Texas. 
Tx-718. Padre Island Beach, I

Tx-719. Padre Island Beach, 2

Tx-720. Padre Island Beach, 3

Tx-721. Padre Island Beach, 4

Tx-722. Padre Island Beach, 5

Tx-723. Padre Island Beach, 6

Tx-724. Padre Island Beach, 7

Tx-725. Padre Island Beach, 8

Tx-726. Padre Island Beach, 9

Tx-727. Padre Island Beach, 10
$7180 \pm 120$

5230 в.C.

$6840 \pm 120$

4890 B.C.

$4590 \pm 70$

2640 B.C.

$1240 \pm 70$

A.D. 710

$2150 \pm 90$

200 B.C.

$5600 \pm 100$

3650 B.C.

$5760 \pm 100$ 3810 B.C.

$6280 \pm 110$ 4330 в.c.

$5480 \pm 100$ 3530 в.c.

$5500 \pm 100$

3550 B.c.

General Comment: (E.W.B.): dates establish existence on continental shelf of an old source for Recent Gulf-beach shell material. Probably shells are being eroded from lagoon sediments deposited during lower stand of sea level.

Tx-760. Laguna Madre Land Cut \#7

$30,860 \pm 1710$

28,910 B.c.

Shell (Mercenaria mercenaria) from surface of spoil bank, E side Intracoastal Canal, opposite Banderia Point, Laguna Madre, Texas $\left(26^{\circ}\right.$ $53^{\prime} 45^{\prime \prime} \mathrm{N}$ Lat, $97^{\circ} 27^{\prime} 40^{\prime \prime} \mathrm{W}$ Long). Originally dredged from ca. $-3.4 \mathrm{~m}$. From interglacial, interstadial or Holocene beach rock (part of Ingleside Barrier complex?) Several mm. of surface material removed with $\mathrm{HCl}$ before submission, to eliminate coatings of younger carbonate and weathered, leached surfaces. Coll. 1968 by Behrens and Kessler; subm. by Behrens. Comment (E.W.B.): date establishes major age difference between 2 very similar deposits: present Padre I. Gulf beach and beachrock within Laguna Madre. Date agrees with high stand of sea level postulated by Milliman and Emery (1968).

\section{North Padre Island series, South Texas}

Shells (Mulinia sp.) from general depth of $18.9 \mathrm{~m}$ on $\mathrm{N}$ part of Padre I. (South Bird quad.), $10 \mathrm{mi} \mathrm{S}$ of Bob Hall pier (27 $27^{\prime} \mathrm{N}$ Lat, $97^{\circ} 18^{\prime} \mathrm{W}$ Long). Samples are rotary drill cuttings from shell bed at 
base of Padre I. sand. Coll. 1968 and subm. by K. A. Dickinson, Office of Marine Geol. and Hydrol., U.S. Geol. Survey, Corpus Christi, Texas.

\section{Tx-800. North Padre, 04-1}

\section{Tx-801. North Padre, 04-2}

$27,380 \pm 1100$ 25,430 в.c.

$29,980 \pm 1070$ 28,030 в.c.

Comment (K.A.D.): shell bed is believed to represent lagoon deposition during last Pleistocene sea-level rise. Dates fit Shepard's (1963, Fig. 3) curve showing sea level ca. $15.2 \mathrm{~m}$ below present from 30,000 to 26,000 B.P. Shell bed is probably from about same horizon as Fisk's Mulinia sp. bed with $\mathrm{C}^{14}$ age of $23,400 \pm 1800$ (0-630, Sample 19; Fisk, 1959, p. 123, 149). Fisk considered this age anomalously young.

\section{Oolite coating series, Baffin Bay, Texas}

Oolites are sand grains with concentric $\mathrm{CaCO}_{3}$ coatings. Assays in table below result from development of method whereby coatings can be serially removed from sand grain nucleus and coating fractions dated. Oolites were taken from 0.25 to $0.30 \mathrm{~mm}$ fraction of sand, chosen for its high percentage of oolitic grains, few uncoated shell fragments and foraminifera tests, and maximum number of grains with non-carbonate nuclei. Serial stripping of coatings was accomplished by calculating volume of $3 \mathrm{~N} \mathrm{HCl}$ necessary to dissolve a desired weight of $\mathrm{CaCO}_{3}$ from previously weighed sand sample. Examination of thin secs. verified nearly uniform removal of coatings. For complete statement of technique, see Frishman (1969).

Material is from swash zone along windward shore at Kleberg Point, Baffin Bay, a normally hypersaline bay on S Gulf coast of Texas ( $27^{\circ} 17^{\prime} \mathrm{N}$ Lat, $97^{\circ} 37^{\prime} \mathrm{W}$ Long). Coll. 1968 and subm. by S. A. Frishman and E. W. Behrens, Dept. Geol. Sciences, Univ. of Texas, Austin.

General Comment (S.A.F.): except for Tx-698, 713, and 716, agreement of triplicate samples indicates uniformity of stripping process. Average age of total carbonate in each sample ( $\mathrm{Tx}-702,-703)$, obtained by dissolving entire sample in excess of acid, is older than average age of coatings, since older carbonate nucleus is included. $\mathrm{C}^{14}$ enrichment (ave. $\delta \mathrm{C}^{14}=+54.7 \pm 1.8 \%$ ) in outer $1 / 5$ of coatings means that at least some of coatings (ca. $27 \%$ by weight) were formed after beginning of nuclear bomb testing in early 1950's. In general, dates show that coating has proceeded sporadically for $730 \mathrm{yr}$, the extrapolated age of initiation of oolite formation in this sample. This extrapolation is made on a plot of $\mathrm{C}^{14}$ vs. \% coating removed by acid leaching.

\section{B. Baffin Bay sediment study, South Texas coast}

Sediments deposited in Baffin Bay, S Gulf coast of Texas, in study of Holocene depositional history of bay. Coll. by Behrens and assocs.; subm. by E. W. Behrens. 
TABle 1

\begin{tabular}{|c|c|c|}
\hline $\begin{array}{l}\text { Sample name and } \\
\text { coating fraction } \\
\text { (by weight) }\end{array}$ & $\begin{array}{l}\mathrm{C}^{14} \text { age } \\
(\mathrm{yr})\end{array}$ & $\begin{array}{l}\delta \mathrm{C}^{14} \\
(\%)\end{array}$ \\
\hline Tx-697. BB-a, outer $1 / 5$ & anomalous & $61.0 \pm 9.1$ \\
\hline Tx-712. BB-b, outer $1 / 5$ & anomalous & $55.0 \pm 8.2$ \\
\hline Tx-715. BB-c, outer $1 / 5$ & anomalous & $48.0 \pm 7.6$ \\
\hline Tx-698. BB-a, middle $2 / 5$ & $230 \pm 70$ & $-28.5 \pm 6.2$ \\
\hline Tx-713. BB-b, middle $2 / 5$ & $90 \pm 60$ & $-11.4 \pm 5.6$ \\
\hline Tx-716. BB-c, middle $2 / 5$ & $70 \pm 50$ & $-9.1 \pm 5.0$ \\
\hline Average, middle $2 / 5$ & $130 \pm 40$ & \\
\hline Tx-699. BB-a, inner $2 / 5$ & $500 \pm 70$ & $-60.5 \pm 7.0$ \\
\hline Tx-714. BB-b, inner $2 / 5$ & $530 \pm 70$ & $-64.0 \pm 6.0$ \\
\hline Tx-717. BB-c, inner $2 / 5$ & $550 \pm 70$ & $-66.2 \pm 5.7$ \\
\hline Average, inner $2 / 5$ & $530 \pm 40$ & \\
\hline Tx-702. BB-a, total $\mathrm{CaCO}_{3}$ & $\begin{array}{l}410 \pm 80 \\
500 \pm 60\end{array}$ & $\begin{array}{l}-50.2 \pm 6.8 \\
-60.5 \pm 5.4\end{array}$ \\
\hline $\begin{array}{l}\text { Tx-703. } \\
\text { BB-b, total } \mathrm{CaCO}_{3}( \\
\text { (2 runs) }\end{array}$ & $440 \pm 70$ & $-53.6 \pm 6.1$ \\
\hline Average, total $\mathrm{CaCO}_{3}$ & $\begin{array}{l}470 \pm 50 \\
440 \pm 50\end{array}$ & \\
\hline
\end{tabular}

Tx-568. Baffin Bay 3, 94 to $97 \mathrm{~cm}$

Carbonate from marl 94 to $97 \mathrm{~cm}$ below sediment-water interface, $15.2 \mathrm{~m} \mathrm{~N}$ of Marker 58, Baffin Bay Channel, Lower Baffin Bay $\left(27^{\circ}\right.$ $17^{\prime} \mathrm{N}$ Lat, $97^{\circ} 28^{\prime} \mathrm{W}$ Long). Marl (18.5\% terrigenous clay, $81.5 \%$ $\mathrm{CaCO}_{3}$ ) was a layer within core of regularly laminated bay-center mud from hypersaline bay. Sample split into 2 parts, prepared and counted separately; $2440 \pm 80,2170 \pm 90$. Comment: see comment on Baffin Bay Core series, below.

\section{Baffin Bay Core series}

Shells, mixture of small species native to grass flats, from cores obtained $10 \mathrm{mi}$ ESE of Riviera Beach near mouth of Baffin Bay, Texas coast $\left(27^{\circ} 15^{\prime} 00^{\prime \prime} \mathrm{N}\right.$ Lat, $97^{\circ} 30^{\prime} 00^{\prime \prime} \mathrm{W}$ Long). From Holocene sediments deposited on grass flat, unconformably overlying Pleistocene surface and overlain by restricted hypersaline bay mud. Coll. 1968. In sample titles, letter indicates core, and numbers are depth $(\mathrm{cm})$ below bay bottom.

Tx-755. Baffin Bay $D, 220$ to 230 
Tx-753. Baffin Bay D, 240 to 250

Tx-752. Baffin Bay D, 250 to 260

Tx-751. Baffin Bay D, 260 to 270

Tx-748. Baffin Bay $D, 270$ to 300

Tx-761. Baffin Bay D, 300 to 325

Tx-762. Baffin Bay D, 325 to 350

Tx-763. Baffin Bay D, 350 to 375

Tx-756. Baffin Bay E, 202 to 233
$6670 \pm 550$

4720 в.c.

$5770 \pm 140$

3820 B.C.

$5800 \pm 100$

3850 в.c.

$5640 \pm 100$

3690 B.c.

$6060 \pm 140$

4110 B.C.

$5420 \pm 220$

3470 B.C.

$6080 \pm 120$

4130 в.c.

$5620 \pm 120$

3670 B.c.

$3750 \pm 80$

1800 B.C.

Tx-757. Baffin Bay C, 350

General Comment on Baffin Bay 3 and Core series (E.W.B.): dates indicate shelly, muddy sands deposited on grass flats under nearly normal salinity ca. 6000 to 5000 B.P. (Tx-761-763, 748, 751-756). Grass flats seldom flourish in water deeper than $1 \mathrm{~m}$, so sea level was ca. $4 \mathrm{~m}$ below present level; this agrees well with results in Florida (Scholl et al., 1969). Between 5000 and 3500 B.P. (Tx-754, 755, 757) major circulation change caused bay to become restricted and hypersaline, which it still is. Marls of Tx-568, 758 represent time of especially intense precipitation of nonskeletal $\mathrm{CaCO}_{3}$ under these conditions.

\section{Kleberg Point series}

Shell (mostly Anomalocardia cuneimeris) from genetically related group of spits at Kleberg Point, N shore Baffin Bay, between Alazan Bay and Cayo del Grullo (27 $17^{\prime} \mathrm{N}$ Lat, 97 $37^{\prime} \mathrm{W}$ Long). Coll. 1967. Some samples split and 2 parts prepared and counted separately, as shown. Samples listed in presumed order of increasing age, based on detailed mapping.

\section{Tx-733. Kleberg Point G \\ Tx-728. Kleberg Point A \\ Tx-729. Kleberg Point B $830 \pm 60$ and $850 \pm 70$.}

$$
\begin{array}{r}
960 \pm 60 \\
\text { A.D. } 990 \\
1440 \pm 90 \\
\text { A.D. } 510
\end{array}
$$$$
\text { A.D. } 1110
$$ 
Tx-730. Kleberg Point C

$1950 \pm 90$ and $1970 \pm 60$.

10 B.C.

Tx-731. Kleberg Point D

$1960 \pm 60$

$1060 \pm 90$ and $1950 \pm 80$.

10 B.C.

Tx-735. Kleberg Point 2a

$2220 \pm 70$

270 B.C.

Tx-732. Kleberg Point F

$2280 \pm 90$

330 B.C.

$2280 \pm 60$

Tx-734. Kleberg Point la

330 B.c.

$2200 \pm 80$ and $2350 \pm 80$.

Tx-747. Kleberg Point 3a

$2900 \pm 90$

950 в.c.

General Comment: see comment for Kleberg Lagoon series, below.

\section{Kleberg Lagoon series}

Marl from bottom of lagoon at Kleberg Point (see Kleberg Point series, above). From base of closed-lagoon-algal mat sequence that began when sand spits closed lagoon from Baffin Bay. Sequence underlain by open-bay shelly mud and overlain by algal mat-evaporite sediments. Coll. 1968.

Tx-759. Kleberg Lagoon RBB 62

$1100 \pm 100$

From $62 \mathrm{~cm}$ below bottom in core near center of lagoon.

\section{Tx-758. Kleberg Lagoon BB 100}

$2660 \pm 270$

From $100 \mathrm{~cm}$ below sediment-water interface in core $S$ of center of lagoon.

General Comment on Kleberg Point and Kleberg Lagoon series (E.W.B.): dates indicate a group of shelly spits grew from 2900 to 1440 B.P. (Tx728 through 732, 734, 735, 747), forming Kleberg Lagoon and separating it from Baffin Bay; algal mats then flourished within lagoon. Four discrepancies exist: 1) Tx-729 out of order; unexplained but might be sampling error, 2) currene active spit dates 960 в.P. (Tx-733); probably indicates old shells retained in active spit, 3) older spit (Tx-747) has older date than underlying marl $(\mathrm{Tx}-758)$; if age of spit is corrected for old shells incorporated in it, as in 2), above, discrepancy disappears, 4) coring has shown that algal mats began to flourish immediately after formation of spit dating 2280 B.P. (Tx-734), but at base of mat sequence is marl dating 1100 B.P. (Tx-759). No reason to believe there was no deposition during this $1100 \mathrm{yr}$ interval. If old-shell correction is applied to age of this spit, as in 2), above, marl formation follows spit formation within ca. $200 \mathrm{yr}$. 


\section{Reef tract sand series, Florida keys}

\section{Florida}

Carbonate sand (abraded fossil debris and mud pellets) from reef tract near Plantation and Upper Matecumbe Keys, Florida. Dated to study age of sands of outer Florida reef tract relative to age of sands near Florida Keys which show less evidence of early diagenesis. Coll. 1966 by P. Braithwaite; subm. by B. W. Boyer, Dept. of Geol. Sci., Univ. of Texas, Austin.

Tx-834. Plantation Key, 571

$2260 \pm 70$

From surface of sediment; water depth ca. $6.1 \mathrm{~m}$; $2.9 \mathrm{mi} \mathrm{SE}$ of Plantation Point, Plantation Key (24 $55^{\prime} \mathrm{N}$ Lat, $80^{\circ} 33^{\prime} \mathrm{W}$ Long).

Tx-836. Plantation Key, 567

$1890 \pm 100$

From top $2.5 \mathrm{~cm}$ of sediment; water depth ca. $4.6 \mathrm{~m}$; $1.8 \mathrm{mi} \mathrm{SE}$ of Plantation Point, Plantation Key (24 $56^{\prime} \mathrm{N}$ Lat, $80^{\circ} 33^{\prime} \mathrm{W}$ Long).

Tx-835. Upper Matecumbe, 514 A.D. 340

From surface of sediment; water depth ca. $4.0 \mathrm{~m}$; $1.3 \mathrm{mi} \mathrm{SE}$ of Islamorada, Upper Matecumbe Key (24 $55^{\prime} \mathrm{N}$ Lat, $80^{\circ} 36^{\prime} \mathrm{W}$ Long). General Comment (B.W.B.): dates suggest back reef sands become older farther offshore from keys. Dates do not seem consistent with hypothesis that lithified pellets and diagenetically altered skeletal debris, which form large percentage of some samples, are relict Pleistocene material.

\section{FM 1144 caliche series, South Texas}

Calcite caliche samples from cuts in top of hill on Farm Rd. 1144, $6 \mathrm{mi} \mathrm{W}$ of Karnes City, Texas (28 $52^{\prime} 31^{\prime \prime} \mathrm{N}$ Lat, $97^{\circ} 59^{\prime} 00^{\prime \prime} \mathrm{W}$ Long). Present soils are silty clay loams of subhumid climate, developing from caliche, relict soil material formed under arid conditions from soft silty Catahoula Tuff bedrock. Caliche is of 2 types: firm massive caliche capping a rounded hill, and soil-joint fillings and horizontal tributary veins in bedrock slightly downhill. Coll. 1967 by Eargle, Ingerson, and Valastro; subm. by D. H. Eargle, Uranium Sec., Branch of Rocky Mt. Mineral Resources, U.S. Geol. Survey, Austin, Texas.

Tx-461. FM 1144, A: vein caliche

$19,730 \pm 430$

Vein caliche, .6 to $.9 \mathrm{~m}$ below surface. 17,780 в.c.

Tx-462. FM 1144, B: caliche matrix

$16,350 \pm 280$

Caliche matrix .6 to $.9 \mathrm{~m}$ below surface.

14,400 в.c.

Tx-634. FM 1144, \#1: vein caliche

$13,750 \pm 230$

Vein, .9 to $1.1 \mathrm{~m}$ below surface.

11,800 B.c. 
Tx-635. FM 1144, \#2: caliche matrix

Massive caliche $1.1 \mathrm{~m}$ below surface, ca. $30.5 \mathrm{~m}$ from Tx-634.

Tx-636. FM 1144, \#3: caliche matrix

$18,190 \pm 340$

Massive caliche $1.1 \mathrm{~m}$ below surface, ca. $35 \mathrm{~m}$ from Tx-634.

Tx-637. FM 1144, \#4: joint filling

$20,310 \pm 430$

Joint filling .9 to $1.1 \mathrm{~m}$ below surface, near Tx-634.

Tx-638. FM 1144, \#5: vein caliche

$16,920 \pm 310$

14,970 в.с.

Vein, .9 to $1.1 \mathrm{~m}$ below surface, same place as Tx-634.

General Comment (D.H.E.): relative uniformity of dates from massive caliche matrix reflects its uniform structure and impervious nature. Greater variation in dates from veins and joint fillings indicates variable admixtures of $\mathrm{CaCO}_{3}$ derived from calcareous bedrock. Dates refer to time of very dry climate of late Wisconsin, indicated by geologic evidence in SW U.S. and N Mexico.

\section{Lacustrine Samples, West Texas and Chihuahua}

Samples coll. and subm. by C. C. Reeves, Jr., Dept. of Geosciences, Texas Tech Univ., Lubbock; comments by C.C.R., Jr.

\section{Tx-639. Blackwater Draw HAL-1}

$32,550 \pm 1600$

Carbonate rock from $\mathrm{W}$ side Blackwater Draw ca. $10 \mathrm{mi} \mathrm{N}$ of Amherst, Lamb Co., Texas ( $35^{\circ} 10^{\prime} \mathrm{N}$ Lat, $102^{\circ} 25^{\prime} \mathrm{W}$ Long), about halfway up from bottom of draw. Assoc. with ponding of Blackwater Draw. Coll. 1968. Comment: shows ponding during Terry Subpluvial and desiccation during Rich Lake Interpluvial.

\section{Tx-689. Mound Lake, W}

$25,460 \pm 860$

Lacustrine carbonate (dolomite) from deep erosional cut, W side playa of Mound Lake, Terry Co., Texas $\left(33^{\circ} 14^{\prime} \mathrm{N}\right.$ Lat, $102^{\circ} 05^{\prime} \mathrm{W}$ Long), immediately $\mathrm{S}$ of Cities Service brine pit. Dolomite is overlain by Tahoka clay, underlain by Rich Lake clay. See also Tx-270-273 (Radiocarbon, 1966, v. 8, p. 459), Tx-327 and 328 (ibid., 1968, v. 10, p. 387), Tx-549-552 (ibid., 1970, v. 12, p. 252). Coll. 1968. Comment: fixes maximum age for Tahoka Pluvial; dates Rich Lake dolomite.

\section{Tx-749. Rich Lake, Texas}

$16,810 \pm 820$

14,860 в.c.

Shells from erosional cut at $\mathrm{N}$ end of Rich Lake, $7 \mathrm{mi}$ NE of Brownfield, Terry Co., Texas (33 $18^{\prime} \mathrm{N}$ Lat, $102^{\circ} 12^{\prime} \mathrm{W}$ Long). Apparently in Tahoka Clay sec. Coll. 1968. Comment: dates age of enclosing clay. 
$15,640 \pm 1730$

Tx-750. Loop 289-1 basin

13,690 B.c.

Shells from clay zone near top of lacustrine sec., E side of Loop 289 basin, SW side of Lubbock, Texas (33 $35^{\prime} \mathrm{N}$ Lat, $101^{\circ} 58^{\prime} \mathrm{W}$ Long). From lacustrine clay with mammoth bones. Coll. 1968. Comment: dates time of last filling of this type of basin.

Tx-640. Lake Palomas, Chihuahua, B

Carbonate rock from middle terrace of pluvial lake in Lake Palomas Basin, Chihuahua, Mexico, at La Mota Point $\left(31^{\circ} 20^{\prime} \mathrm{N}\right.$ Lat, $107^{\circ} 30^{\prime}$ $\mathrm{W}$ Long). Terrace is Pleistocene, expected age: $<10,000 \mathrm{yr}$ old. Coll. 1967. Comment: carbonate is spring deposit over Pleistocene shore, source of carbonate being Paleozoic strata to the W. Cf. Tx-464, 27,150 \pm 1060 (Radiocarbon, 1968, v. 10, p. 389) from high La Mota shoreline in same lake basin.

\section{PALEOBOTANICAL SAMPLES}

\section{Boriack Peat Bog series}

Peat samples from 2 cores in Boriack Peat Bog, $6.7 \mathrm{mi} \mathrm{SW}$ of Lexington, Lee Co., central Texas, on $\mathrm{N}$ bank of Owens Branch, a tributary of Yegua Creek ( $30^{\circ} 21^{\prime} 48^{\prime \prime} \mathrm{N}$ Lat, $97^{\circ} 05^{\prime} 92^{\prime \prime}$ W Long). Coll. 1969 by Bryant and Valastro; subm. by V. M. Bryant, Jr., Dept. Botany, Univ. of Texas, Austin.

Tx-837. Boriack Core I, 40 to $50 \mathrm{~cm}$

Tx-838. Boriack Core I, 240 to $250 \mathrm{~cm}$

Tx-839. Boriack Core I, 440 to $450 \mathrm{~cm}$

Tx-840. Boriack Core I, 500 to $527 \mathrm{~cm}$

Tx-841. Boriack Core II, 40 to $50 \mathrm{~cm}$

Tx-842. Boriack Core II, 240 to $250 \mathrm{~cm}$ $\mathbf{3 7 0 0} \pm 90$ 1750 B.c.

$9850 \pm 160$ 7900 в.C.

$13,810 \pm 210$ 11,860 в.c.

$15,460 \pm 250$ 13,510 в.c.

$3850 \pm 80$ 1900 B.c.

$10,010 \pm 160$ 8060 B.c.

$14,410 \pm 220$

Tx-843. Boriack Core II, 440 to $450 \mathrm{~cm}$ 12,460 B.c.
neral Comment (V.M.B.): dates indicate following vegetational sequence for central Texas: before 14,000 B.P., temperate deciduous woodland with some conifers; 14,000 to 10,000 B.P., transition to parkland; after 10,000 B.P., loss of parkland elements, replacement by oak savannas; 7000 to 4500 B.P., hot and/or dry altithermal conditions; 4500 в.P. to present, increasing aridity. This record and that of Hershop Bog ca. 70 mi SSW of Boriack (Tx-837-843, this list) indicate trend toward less mesic conditions in central Texas during the past 10,000 yr. 


\section{A. George C. Davis site, East Texas}

Charcoal samples from George C. Davis site (41CE19), E side Neches R. valley $6 \mathrm{mi} \mathrm{SW}$ of Alto, Cherokee Co., Texas $\left(31^{\circ} 35^{\prime} \mathrm{N} \mathrm{Lat}, 95^{\circ} 10^{\prime}\right.$ $\mathrm{W}$ Long). Site is a mound and village site of Alto focus, early Caddoan; stylistic cross-dating suggests it may be earliest Caddo site known. Major excavations in 1939-41 (Newell and Krieger, 1949) limited to small portion of site (Mound A and vicinity), was source of previous dated samples, all from same house: C-153, $1553 \pm 175$ (Libby, 1955, p. 108); M-1186, $655 \pm 75$ (Radiocarbon, v. 5, 1963, p. 241); Tx-105, $1120 \pm 90$ (Radiocarbon, v. 6, 1964, p. 155). Present samples are from different portion of site (Mounds B and $\mathrm{C}$ and vicinity) but ceramics indicate same cultural affiliation. Coll. 1968-69 and subm. by D. A. Story, Dept. Anthropol., Univ. of Texas, Austin; comments by D.A.S. except as noted. In titles, "F" stands for "Feature."

\section{Geo. Davis site, Feature 120 series}

Feature 120 is small circular structure overlain by washed fill of Mound $\mathrm{B}$; thought to be earliest structure excavated thus far under Mound B.

Tx-914A. Geo. Davis 52, F120, corn

Tx-914B. Geo. Davis 52, F120, wood

Tx-914 sample was from fill of Post Mold 2. Sorted under low magnification; Tx-114A believed to be mostly or entirely corn, Tx-914B wood. Comment (S.V., Jr.): discrepancy about as expected; our experience is that corn produces dates ca. $300 \mathrm{yr}$ too recent.

\section{Tx-925. Geo. Davis 69, F120}

$$
1150 \pm 70
$$

Combined sample from fill of Post Molds 1 through 6.

General Comment: Tx-914B and Tx-925 in good agreement; house probably dates in 9 th century. A.D.

\section{Geo. Davis site, Feature 115 series}

Feature 115 is subrectangular structure overlain by Mound B fill and washed Mound B fill.

Tx-920. Geo. Davis 60, F115, subfloor

$1150 \pm 70$ floor.

Scattered charcoal from midden-stained soil underlying prepared

Tx-923. Geo. Davis 67-71, F115

$1020 \pm 100$

From fill of Post Molds 1 and 2. 
General Comment: dates agree within $1 \sigma$; house probably dates in 9 th or 10th century A.D. Midden, as expected, dates slightly earlier.

\section{Geo. Davis site, Feature 108 series}

Feature 108 is a subrectangular structure overlain by washed fill of Mound B.

Tx-916. Geo. Davis 55, F108

$900 \pm 70$

Scattered charcoal from thin midden overlying prepared floor.

Tx-915. Geo. Davis 54, F108

A.D. 1120

$830 \pm 70$

Scattered charcoal from midden just outside Feature 108 and same elevation as $\mathrm{Tx}-916$.

General Comment on $T x-916, T x-915$ : good agreement between samples; house probably dates in latter part of 11 th century A.D.

Geo. Davis site, Feature 111 series

Feature 111 is large circular structure (probably ceremonial) underlying fill of Mound $\mathbf{B}$.

Tx-911. Geo. Davis 49, F111 A.D. 1080

From fill of Post Mold 20.

Tx-912. Geo. Davis 50, F111

A.D. 1080

$$
870 \pm 160
$$

Charred horizontal beam in depression along exterior wall.

Tx-918. Geo. Davis 57, F111

A.D. 1140

$810 \pm 70$

Charred horizontal beam in depression along exterior wall between Posts 17 and 21.

Tx-917. Geo. Davis 56, F111

$980 \pm 70$

From fill of several small wall posts in depression along exterior wall.

Tx-905. Geo. Davis 28, F111, overburden A.D. 1100

$$
850 \pm 100
$$

Scattered charcoal from midden overlying prepared floor.

Tx-921. Geo. Davis 65, F111, overburden

$$
950 \pm 70
$$

Scattered charcoal from midden overlying prepared floor. General Comment: dates in good agreement; house probably dates between A.D. 950 and A.D. 1100 .

\section{Geo. Davis site, Feature 112 series}

Feature 112 is circular structure underlying Mound B fill; believed contemporary with other sub-Mound B structures except Feature 120. 
Tx-919. Geo. Davis 58, F112 $1310 \pm 80$

From fill of Post Mold 10.

Tx-924. Geo. Davis 68, F112 A.D. 640

Combined sample from fill of Post Molds 1 through 11 .

$940 \pm 70$

A.D. 1010

$830 \pm 70$

Tx-910. Geo. Davis 37, F112

A.D. 1120

From fill in probable post trench (Feature 114).

General Comment: Tx-924 and Tx-910 agree within $1 \sigma$; house probably dates between A.D. 950 and 1150. Tx-919 anomalous, presumably not relevant; no explanation for discrepancy.

Geo. Davis site, sub-Mound B midden series B fill.

Samples from cultural zone just below Mound B and washed Mound

Tx-674. Geo. Davis 4, sub-Mound $B$

$1420 \pm 100$

From below Feature 108, Excav. Unit 3A, elev. 99.26 to $99.06 \mathrm{~m}$.

Tx-675. Geo. Davis 10, sub-Mound B

$1010 \pm 80$

Excav. Unit 3C, 99.36 to $99.16 \mathrm{~m}$.

Tx-676. Geo. Davis 11, sub-Mound B

Excav. Unit 3B, 99.17 to $99.06 \mathrm{~m}$.

Tx-677. Geo. Davis 12, sub-Mound B A.D. 940

$1120 \pm 80$ A.D. 830

General Comment: except for Tx-674, dates form good stratigraphic series. Tx-674 seems early, but lower part of sub-Mound B midden poorly sampled.

Tx-678. Geo. Davis 22, Excav. Unit 4

$1430 \pm 160$

From lower part of occupation zone in village remains $\mathrm{S}$ of Mound B. Large error quoted due to small sample size. Comment: date early, cannot be unequivocally taken as true age unless other similar dates are obtained. Assoc. ceramics are Alto focus.

\section{Tx-913. Geo. Davis 51, Feature 119}

$1150 \pm 80$ A.D. 800

Scattered charcoal from introduced layer of greenish sand at bottom of shaft burial with elaborate offerings, Feature 119, in Mound C; thought to be earlier than Mound B. Assoc. of charcoal with burial not certain, but lack of other midden debris suggests charcoal was deliberate inclusion. Comment: if date does apply to burial, burial dates well before Mound B. 
Geo. Davis site, Feature 110 series

Feature 110 is scattered series of post molds in Excavation Unit 6, representing at least one structure, near edge of terrace $S$ of Mound B. Samples are from just below plow zone.

\section{Tx-906A. Geo. Davis 29, F110, corn}

\section{A.D. 1240}

$710 \pm 70$

Tx-906B. Geo. Davis 29, F110, wood

A.D. 820

Tx-906 was from fill in lower part of Post Mold 1. Sorted under low magnification into corn sample and wood sample. Comment (S.V., $\mathrm{Jr}$.): discrepancy between corn and wood is somewhat larger than expected from our experience. Tx-906B should be proper radiocarbon age of sample; large error due to small sample size.

Tx-926. Geo. Davis 70, F110

$1000 \pm 60$

From fill in lower part of Post Mold 1; should be same age as Tx-906B.

Tx-907. Geo. Davis 30, F110

$\begin{aligned} 960 & \pm 70 \\ \text { A.D. } & 990\end{aligned}$

From fill in lower part of Post Mold 2.

Tx-922. Geo. Davis 66, F110

$1070 \pm 70$

From fill in lower part of Post Mold 2. Sample was split and 2 parts prepared and counted separately: $1000 \pm 70,1140 \pm 100$.

Tx-908. Geo. Davis 31, F110

From fill in lower part of Post Molds 7 and 17.

Tx-909. Geo. Davis 32, F110

From fill in lower part of Post Mold 17.

General Comment: principal overlap of $1 \sigma$ ranges is between A.D. 700 and 1000; dates suggest more than one structure is represented.

General Comment on Davis site dates: long span of occupation indicated. Village remains underlying Mound $B$ and at terrace edge $S$ of Mound B appear to date between A.D. 700 and 1200, with Mound B construction beginning ca. A.D. 1200. Features 108, 111, and 112 immediately under Mound B were probably constructed between A.D. 1000 and 1200. Feature 115 is slightly older, and Feature 120 is at least 100 or $200 \mathrm{yr}$ earlier. Earliest sub-Mound B date, Tx-674, is from midden debris not assoc. with a structure and is out of stratigraphic sequence.

\section{B. Other Texas sites}

\section{Tx-666. Tuck Carpenter site, Texas}

$360 \pm 70$

Charred logs from Burial 10, Tuck Carpenter site (41CP5), $3 \mathrm{mi}$ E of Pittsburg, Camp Co., NE Texas (32 $59^{\prime} 41^{\prime \prime} \mathrm{N}$ Lat, $94^{\circ} 54^{\prime} 53^{\prime \prime}$ 
W Long). Site is a Titus focus (late prehistoric Caddoan) cemetery. Pottery styles suggest 2 time periods; if so, Burial 10 is of the later period. Sample was from near feet of individual. Coll. 1963 by R. L. Turner, Jr.; subm. by E. M. Davis. Comment (E.M.D.): 1st date from a classic Titus focus site; agrees with estimates of age (A.D. 1500-1700) from Whelan complex (early Titus focus): Tx-83, Tx-84 (Radiocarbon, 1964, v. 6, p. 156); Tx-199, Tx-202 (ibid., 1965, v. 7, p. 309-310); Tx-238 through Tx-241 (ibid., 1966, v. 8, p. 461-462). Time spans of complexes may be too small to distinguish on basis of $\mathrm{C}^{14}$ assays.

\section{Sam Kaufman series, Northeastern Texas}

Charcoal samples from House 3, Sam Kaufman site (X41RR1), right bank of Red R. $5.2 \mathrm{mi}$ NW of State Hwy 37 bridge, in Red River Co., Texas (33 $54^{\prime} \mathrm{N}$ Lat, $95^{\circ} 07^{\prime} \mathrm{W}$ Long). Assigned to Sanders focus, Gibson aspect Caddoan (Skinner et al., 1969). Coll. 1968 and subm. by S. A. Skinner and R. K. Harris, Dept. Anthropol., Southern Methodist Univ., Dallas, Texas.
Tx-882. Sam Kaufman 43
A.D. 1080
Tx-883. Sam Kaufman 44
$1000 \pm 70$
A.D. 950
Tx-884. Sam Kaufman 64
A.D. 1040
Tx-885. Sam Kaufman 65
A.D. 1050
$910 \pm 70$
$900 \pm 70$

General Comment (S.A.S. and R.K.H.): dates indicate house was occupied in 11th century A.D., which is consistent with archaeologic evidence.

\section{Price Daniel series, Southeastern Texas}

Human bone fragments from Price Daniel site (41LB3), E side Trinity R. flood plain, $2 \mathrm{mi} \mathrm{N}$ of Liberty, Texas $\left(30^{\circ} 05^{\prime} 30^{\prime \prime} \mathrm{N}\right.$ Lat, $90^{\circ} 47^{\prime} 30^{\prime \prime} \mathrm{W}$ Long). In immediate vicinity of bones were sandy-paste potsherds, fired clay lumps, 2 probable Neo-American arrowpoints, one partial dart point. Subm. by C. D. Tunnell and J. M. Malone, State Archaeologist's office, Austin, Texas. Dating was done on carbonate in bone apatite, following Haynes (1968).

Tx-887. Price Daniel 29-30

$4080 \pm 430$

From Test 1, Levels 1 and 2. Coll. 1967 by Jensen and Tunnell.

\section{Tx-896. Price Daniel 2}

$4500 \pm 160$

2550 в.C.

From Area 1, Levels 3 and 4. Same excavation area as Tx-887 (above) and almost certainly same burial. Coll. 1969 by J. M. Malone. General Comment (J.M.M., E.M.D., S.V., Jr.): from what little is now known, pottery first appears after A.D. 1 in this region (Ambler, 1967, p. 
78-79); thus these dates are at least $2000 \mathrm{yr}$ older than expected. No burial pit visible, so that primary assoc. of bones with potsherds now seems questionable.

\section{Spanish Moss series, Southeastern Texas}

Rangia shell samples from near E edge of cut on $\mathrm{N}$ face of Spanish Moss site (4lGV10), shell midden on $\mathrm{S}$ side Clear Lake ca. $3000 \mathrm{ft}$ W of mouth of Robinson's Creek at SW edge of Houston, Texas $\left(29^{\circ}\right.$ $32^{\prime} \mathrm{N}$ Lat, $95^{\circ} 06^{\prime} \mathrm{W}$ Long). Site has sandy paste pottery of general Goose Creek type, also some sherd-tempered pottery. Coll. 1968 by T. R. Hester and J. E. Corbin; subm. by E. M. Davis.

\section{Tx-690. Spanish Moss, upper}

$740 \pm 70$

From near surface of midden. Sandy-paste pottery and some sherdtempered pottery.

\section{Tx-691. Spanish Moss, lower}

From bottom of midden. Sandy-paste pottery; no sherd-tempered pottery.

General Comment (T.R.H., J.E.C.): dated sample pairs of charcoal and Rangia from nearby Wallisville Reservoir (Radiocarbon, 1970, v. 12, p. 263) indicate Rangia gives ages $200-300$ yr older than charcoal in this environment, although sometimes disparity is less. Two Wallisville charcoal dates $(\mathrm{Tx}-400,1990 \pm 90$; Tx-401, $1780 \pm 100$; ibid., p. 265) indicate earliest pottery there is ca. A.D. 100. Present date Tx-691 suggests pottery appeared in this area a few centuries earlier.

\section{Kyle site, Series 2: snail shells}

Snail shells from Kyle rock shelter (41HI1), E edge of Brazos R. valley SE of Blum, Hill Co., Texas $\left(32^{\circ} 02^{\prime} \mathrm{N}\right.$ Lat, $97^{\circ} 25^{\prime} \mathrm{W}$ Long). Site was stratified; Austin focus lower, Foyah focus higher (Jelks, 1962). For previous dates from site see Radiocarbon, 1964, v. 6, p. 149. Present series dates by M. A. Tamers and F. J. Pearson, Jr., 1963-64 at this lab, but not reported until now; dated to study validity of $\mathrm{C}^{14}$ dates on terrestrial snail shells (Tamers, 1970). Coll. 1959-60 and subm. by E. B. Jelks, Texas Archaeol. Salvage Project, Univ. of Texas, Austin.

Tx-742. Kyle 71, shell

Stratum 5; late to middle Toyah focus.

Tx-743. Kyle 104, shell

Stratum 4; Austin-Toyah focus transition.

Tx-744. Kyle 163, shell

Upper Stratum 1; middle Austin focus.
$1140 \pm 130$ A.D. 810

$$
1980 \pm 80
$$
30 B.C.

$$
1350 \pm 110
$$

A.D. 600 
Tx-745. Kyle 147, shell

Middle Stratum 1; early Austin focus.

Tx-746. Kyle 159, shell

Lower Stratum 1; very early Austin focus.

General Comment (E.M.D.): dates are unrealistically old (except perhaps $\mathrm{Tx}-746)$ but in varying amounts. Significance of variation is discussed by Tamers (1970).

\section{Smith Shelter, Series 3: snail shells}

Snail shell samples from Smith rock shelter (41TV42) on Onion Creek S of Austin, Texas $\left(30^{\circ} 12^{\prime} \mathrm{N}\right.$ Lat, $97^{\circ} 43^{\prime} \mathrm{W}$ Long). Site is stratified, with 11 layers; deepest is Transitional Archaic, most recent is Toyah focus (Suhm, 1957). Present series dated by M. A. Tamers and F. J. Pearson, Jr., 1963-64 at this lab, but not reported until now; dated to study validity of $\mathrm{C}^{14}$ dates on terrestrial snail shells (Tamers, 1970). Coll. 1954-55 and subm. by D. A. Story, Dept. Anthropol., Univ. of Texas, Austin.

Tx-736. Smith 2, shell

$1390 \pm 150$

Sq. N1-N2; B-C; 0 to $15 \mathrm{~cm}$ below surface; mixed layers X and XI, Toyah focus with some European materials.

Tx-737. Smith 33, shell

$1150 \pm 110$

Sq. 0-N1; C-D; 106 to $122 \mathrm{~cm}$ below surface, mixed layers III and IV, Austin focus.

Tx-738. Smith 36, shell

$1400 \pm 80$

Sq. 0-S1; D-E; 229 to $244 \mathrm{~cm}$ below surface. Layer I, Transitional Archaic.

Tx-739. Smith 19, shell

Sq. 0-S1; D-C; 152 to $168 \mathrm{~cm}$ below surface. Layer II; little cultural material but should be either Transitional Archaic or early Austin focus.

Tx-740. Smith B, shell

$1260 \pm 70$

Sq. S1-S2; C-D; 91 to $106 \mathrm{~cm}$ below surface. Layer II, Austin focus.

\section{Tx-741. Smith C, shell} A.D. 860

$1090 \pm 90$

Sq. S1-S2; C-D; 46 to $61 \mathrm{~cm}$ below surface. Layer IX, Austin focus. General Comment (D.A.S.): these and other shell dates from site (Radiocarbon, 1970, v. 12, p. 271) are so inconsistent with stratigraphic sequence and with charcoal dates (ibid., 1964, v. 6, p. 145-146) that they are of no archaeologic significance. 


\section{Loeve series, Laneport Reservoir}

Charcoal samples from Loeve site (41WM133), $3.9 \mathrm{mi}$ SE of Granger, Williamson Co., Texas, on left bank of San Gabriel R. $\left(30^{\circ} 39^{\prime} \mathrm{N}\right.$ Lat, $97^{\circ} 24^{\prime} \mathrm{W}$ Long). Site, buried in flood plain deposit, represents early part of local sequence-short-term camps immediately beside river channel. Samples are from Unit II, clay, and underlying Unit III, basal gravels. No cultural assocs. except for hearths and flint flakes. Coll. 1968 and subm. by F. W. Eddy, Texas Archaeol. Salvage Project, Balcones Research Center, Univ. of Texas, Austin.

\section{Tx-802. Loeve 37}

$7000 \pm 160$ 5050 в.c.

From Fire Hearth 3 in Unit II, just above contact with Unit III. Sample was divided and 2 parts prepared and counted separately: 6810 \pm 160 and $7190 \pm 80$.

\section{Tx-805. Loeve 30}

$6900 \pm 110$

From Fire Hearth 2 in Unit III.

4950 B.C.

General Comment (F.W.E.): site evidently in use ca. 5000 в.C., thus during local Archaic stage.

\section{Dobias-Vitek series, Laneport Reservoir}

Charcoal samples from Dobias-Vitek site (41WM118), $4.2 \mathrm{mi}$ SE of Granger, Texas, on left side San Gabriel R. $\left(30^{\circ} 30^{\prime}\right.$ N Lat, $97^{\circ} 00^{\prime}$ W Long). Site, in Catalpa soil in top of Recent-age flood-plain deposit, represents later part of local sequence-seasonal camps located back from main drainage. Neo-American and Transitional Archaic artifacts found throughout $3.8 \mathrm{ft}$ thick alluvial soil. Coll. 1968-1969 and subm. by F. W. Eddy.

\section{Tx-804. Dobias-Vitek 6}

$1350 \pm 70$

From Fire Hearth 1, Test Pit 1, $0.2 \mathrm{~m}$ below surface of plowed field. Four sand-tempered sherds found in same dug level as hearth. Should date end of Transitional Archaic stage.

\section{Tx-806. Dobias-Vitek 57}

$$
770 \pm 70
$$

From Fire Hearth 3, Test Pit 4, 0.3 to $0.6 \mathrm{~m}$ below undisturbed surface. Perdiz arrowpoint and bone-tempered potsherd immediately overlay hearth. Should date middle of Neo-American stage at site.

General Comment (F.W.E.): dates not inconsistent with archaeologic chronology as now known. More such dates will help us understand relationship between local fluvial history and cultural events.

\section{Tx-688. Agarita site, Texas}

$700 \pm 160$

Charcoal from Feature 4, Unit 16, Area B, Agarita site (41CK30), at confluence of Salt Creek and Colorado R., $6.8 \mathrm{mi}$ W of Robert Lee, Coke Co., Texas, in Robert Lee Reservoir basin ( $31^{\circ} 55^{\prime} \mathrm{N}$ Lat, $100^{\circ}$ 
$37^{\prime} \mathrm{W}$ Long). Site has 2 living surfaces, both with Neo-American components; sample is from more recent surface, which had side-notched and unnotched arrowpoints. Combination of point forms suggests earlier time than ca. A.D. 1500 ascribed to sites $100 \mathrm{mi} \mathrm{N}$ of here with sidenotched points and Rio Grande Glaze V pottery (Parson, 1967). Comment (H.J.S.): date supports archaeologic estimate.

Tx-679. Pavo site, Texas

$190 \pm 80$

Charcoal assoc. with ash pit, Feature 5, at Pavo site (41CK129) on low bluff at $\mathrm{N}$ edge of Colorado R. flood plain, $6 \mathrm{mi} \mathrm{NW}$ of Robert Lee, Coke Co., Texas, in Robert Lee Reservoir basin $\left(31^{\circ} 50^{\prime} \mathrm{N}\right.$ Lat, $100^{\circ} 30^{\prime} \mathrm{W}$ Long). Assoc. with "cloud blower" pipe, presumably of SW origin. Coll. 1968 and subm. by H. J. Shafer. Comment (H.J.S.): date agrees well with Kidder's (1932, p. 169-182) dating of similar pipes at Pecos, A.D. 1500 to 1838.

\section{La Jita series, Texas}

Charcoal samples from La Jita site (41UV21), E side Sabinal R., in La Jita Girl Scout Camp, $3 \mathrm{mi} S$ of Utopia in extreme NE corner of Uvalde Co., Texas (29 $34^{\prime} \mathrm{N}$ Lat, $99^{\circ} 31^{\prime} \mathrm{W}$ Long). Site is 3 burned rock middens and cultural debris in surrounding terrace fill. Principal occupation Middle Archaic (Montell and especially Pedernales dart points); below is Early Archaic with corner-notched (Martindale-like) dart points; above is Late Archaic (Ensor, Frio dart points) and NeoAmerican (Edwards, Scallorn, Perdiz arrow points) with pottery. Coll. 1967 and subm. by T. R. Hester, Dept. Anthropol., Univ. of Texas, Austin, via E. M. Davis. Samples listed in presumed chronologic order, recent to older, based on type assocs.

\section{Tx-687. La Jita 49}

$$
660 \pm 70
$$

N15/E35, Level 2. Neo-American: Scallorn and other side-notched arrow points; bipointed knife.

\section{Tx-684. La Jita 176}

$$
810 \pm 50
$$

N25/E40, Level 3. Mixed Neo-American and Archaic: Sabinal arrow points (local type similar to Scallorn), Pedernales points triangular thinned biface. Sample split and 2 parts prepared and counted separately: $800 \pm 60,810 \pm 90$.

\section{Tx-664. La Jita 86}

$$
710 \pm 70
$$

Test Pit 6, Level 1. Neo-American and Archaic: Perdiz, Ensor-like, Marshall-like points. From thin deposit near edge of site; occupations probably mixed.

\section{Tx-665. La Jita 29}

$910 \pm 80$

N10/E40, Level 2. Mixed early Neo-American and Late Archaic: Montell, Edwards, arrow point fragments. 
Tx-681. La Jita 137

A.D. 960

$990 \pm 60$

N15/E35, Level 3. Mixed early Neo-American and Late Archaic. Frio dart points, Edwards points and arrow point fragments.

\section{Tx-685. La Jita 72}

$1100 \pm 70$

N20/W50, Level 3. Mixed early Neo-American and Late Archaic: Edwards and Pedernales types.

Tx-686. La Jita 147

$1460 \pm 80$

N60/E40, Level 2. Late Middle Archaic: Frio point.

\section{Tx-692. La Jita 32}

N10/E40, Level 4. Late Archaic or Late Middle Archaic: Montell, Pedernales, Marshall-like point.

Tx-682. La Jita 55

A.D. 1030

$1850 \pm 180$

N15/E35, Level 4. Middle Archaic: Pedernales points.

\section{Tx-683. La Jita 160}

$650 \pm 50$

N20/E35, Level 2. Middle Archaic: Pedernales point and other dart point fragments. Sample split; 2 parts prepared and counted separately: $600 \pm 80,690 \pm 70$.

General Comments (T.R.H.): these are 1st dates from SW edge of Edwards Plateau. In general, Neo-American occupations agree in age with those of central Texas (Jelks, 1962, p. 98) though Scallorn points may have lasted much longer here. Edwards seems to be earliest arrow point type, dating from 10th century; Sabinal local type may appear later. Late Archaic dates indicate that period ended ca. A.D. 1000, much later than in either Amistad Reservoir to $W$ or central Texas to NE. Dates on Montell specimens here are much later than those in Amistad Reservoir where they are from 2100 to 2800 B.P. (see comments with Tx-570; Radiocarbon, 1970, v. 12, p. 270). Best date for Pedernales type may be Tx-692; other much later dates, especially Tx-682 and Tx-683, were from rather mixed upper levels containing random Pedernales specimens. Dates of pottery at site not pin-pointed, but Tx-644 is most applicable. (E.M.D.): dates in general are so recent that one suspects some mixture of material.

\section{Parker Midden \# 1 series, Texas}

Charcoal samples assoc. with central slab-lined cooking pit at Parker Midden \#1 (41CX30), ring midden on plateau at head of Simson Creek, $5 \mathrm{mi} \mathrm{NE}$ of Pecos R. near Iraan, in NW Crockett Co., Texas $\left(31^{\circ} 00^{\prime}\right.$ $\mathrm{N}$ Lat, $101^{\circ} 48^{\prime} \mathrm{W}$ Long). Small unifacial scrapers directly assoc. with 
cooking pit. Ensor point was in burned rock area on $\mathrm{S}$ side of midden, presumably same age as cooking pit or later. Coll. 1968 by A. W. Sommer and J. W. Greer; subm. by E. M. Davis.

Tx-645. Parker Midden \#1, 3

$1160 \pm 70$

40 to $50 \mathrm{~cm}$ below surface, Sqs. K, K-1-E, J, J-1-W.

Tx-646. Parker Midden \# 1, 4

$1050 \pm 70$

50 to $60 \mathrm{~cm}$ below surface, Sqs. K, K-1-E, K-1-W.

Tx-647. Parker Midden \#1, 5

Sqs. K, K-1-E, K-1-W, J, J-1-E, J-1-W, in and adjacent to pit. Comment (E.M.D., J.W.G.): date of site appears to be between A.D. 800 and 1000; agrees with estimate by Greer (1968) of probable age of such features.

\section{Arenosa Shelter, Series 3}

Charcoal from Arenosa Shelter (41VV99), right bank of Pecos R., I mi upstream from confluence with Rio Grande $\left(29^{\circ} 42^{\prime} \mathrm{N}\right.$ Lat, $101^{\circ}$ 22' W Long). For previous series from this site see Radiocarbon, 1967, v. 9, p. 444-445, and 1970, v. 12, p. 268. Coll. 1968 and subm. by D. S. Dibble, Texas Archaeol. Salvage Project, Balcones Research Center, Univ. of Texas, Austin.

\section{Tx-696. Arenosa 653, Stratum 9}

From matrix of upper 1/3 of Stratum 9; dates earlier part of Ensor and Frio point occurrence at site.

Tx-701. Arenosa 659, Stratum 21

$3220 \pm 70$ 1270 B.c.

From all levels of Stratum 21; point assocs. principally Langtry, Val Verde, and "Shumla-like" (large barbed form with some morphologic and stratigraphic differences from classic Shumla at this site).

Tx-773. Arenosa 655, Stratum 30L

$4670 \pm 70$

From lower $1 / 2$ of Stratum 30L; earliest occurrence of Pandale points.

General Comment (D.S.D.): dates are close to expectations in terms of previous dates from site. This series and previous dates indicate relatively rapid accumulation of cultural debris and overbank alluvial deposits through late Early Archaic and Middle and Late Archaic periods.

\section{Louisiana and New Mexico}

Tx-680. Poverty Point, Louisiana

$3000 \pm 90$

1050 B.c.

Burned cane from shallow pit below midden exposed in caving $\mathrm{W}$ bank of Bayou Macon, N Sec., Ridge 2, Poverty Point site (41CW2; 
Ford and Webb, 1956), ca. $7 \mathrm{mi} \mathrm{E}$ of Epps, W Carrol Parish, Louisiana (34 $38^{\prime} \mathrm{N}$ Lat, $91^{\circ} 24^{\prime} \mathrm{W}$ Long). Represents early occupation by Poverty Point people in this part of site, before construction of geometric ridges. Coll. 1968 by M. Hillman; subm. by C. M. Webb, 1560 Line Ave., Shreveport, La. Comment (E.M.D.): date agrees within $1 \sigma$ with M-403, $2850 \pm 250$ (Crane and Griffin, 1958); L-195, $2860 \pm 90$ (Broecker et al., 1956); O-66, $3150 \pm 120$ (Brannon et al., 1957); and is close to several others from site (Ford and Webb, 1956, p. 121-122). However, Webb (1968, p. 318) suggests site may have been established considerably before this time. Present sample is of cane, raising question of possible fractionation, which might make date erroneously young by as much as 2 centuries (Bender, 1968).

\section{Tx-886. Yucca Cave, New Mexico}

$2930 \pm 60$ 980 B.C.

Wooden stick from crossed arrangement of sticks partly under large breakdown rock at Yucca Cave (Site C-27), large collapse sink in convex slope of Capitan Excarpment, 1/2 mi SW of mouth of Yucca Canyon, Carlsbad Caverns Natl. Monument, New Mexico $\left(30^{\circ} 05^{\prime} 44^{\prime \prime} \mathrm{N}\right.$ Lat, $104^{\circ} 35^{\prime} 27^{\prime \prime} \mathrm{W}$ Long). Sticks had been partly crushed by breakdown rock, on top of which is stalagmite $80 \mathrm{~cm}$ high and $15 \mathrm{~cm}$ average diam. No cultural assocs. Coll. 1969 by E. R. Anderson; subm. by P. F. van Cleave, Acting Supt., Carlsbad Caverns Natl. Monument, New Mexico. Comment (E.M.D.): date is maximum for fall of breakdown rock, and time of human use of cave.

\section{Mexico}

\section{La Calsada series, Nuevo Leon}

Charcoal samples from La Calsada site (NL103), overlooking Río Pilón valley, Ejido de Casillas, Municipio de Rayones, Nuevo Leon, Mexico (ca. $25^{\circ} 00^{\prime} \mathrm{N}$ Lat, $100^{\circ} 05^{\prime} \mathrm{W}$ Long). Site has 5 principal stratigraphic units: Unit 1-2 (highest) with arrow points and double-sidenotched dart points; Unit 3 with earliest side-notched points, broad oval and triangular (Tortugas) dart points; Unit 4, stemmed dart points; Unit 5, Lerma and double-stemmed points; Unit 6, diamond-shaped and small leaf-shaped points. Each unit excavated in $10 \mathrm{~cm}$ levels numbered from top downward within unit. Samples coll. on screen. Coll. 1965 by C. R. Nance; subm. by Nance and J. F. Epstein, Dept. Anthropol., Univ. of Texas, Austin. Samples listed in order of increasing depth; in titles, " $U$ " is unit, " $L$ " is level.

Tx-707. La Calsada C-5: U1-2, L2

Tx-706. La Calsada C-4: U1-2, L3

Tx-709. La Calsada C-11: U3, L8
$580 \pm 60$

A.D. 1370

$1050 \pm 80$

A.D. 900

$4400 \pm 90$

2450 B.c. 
Tx-710. La Calsada C-12: U3, L9

Tx-708. La Calsada C-10: U3, L9

Tx-764. La Calsada C-18: U4, L3

Tx-768. La Calsada C-20: U4, L2

Tx-767. La Calsada C-19: U4, L4

Tx-711. La Calsada C-13: U4, L1

Tx-765. La Calsada C-14: U4, L2

Tx-769. La Calsada C-24: U5, L2

Tx-766. La Calsada C-23: U5, L2

Tx-354. La Calsada C-3: U5, L2

Tx-770. La Calsada C-27: U5, L5

Tx-771. La Calsada C-28: U5, L7

Tx-353. La Calsada C-2: U5, L7

Tx-352. La Calsada C-1: U6, L2

Tx-772. La Calsada C-30: U6, L2

Tx-875. La Calsada C32-33: U6, L5
$5400 \pm 100$

3450 B.C.

$4310 \pm 90$

2360 B.C.

$4790 \pm 90$

2840 B.c.

$5940 \pm 160$

3990 B.C.

$6520 \pm 150$

4570 B.C.

$5710 \pm 120$

3760 B.C.

$4460 \pm 120$

2510 B.C.

$7040 \pm 180$

5090 в.c.

$7990 \pm 130$

6040 B.c.

$7920 \pm 190$

5970 в.c.

$9310 \pm 160$

7360 B.c.

$8610 \pm 100$

6660 в.c.

$9270 \pm 150$

7320 в.c.

$9940 \pm 150$

7990 B.c.

$$
9670 \pm 70
$$

7720 B.c.

$10,640 \pm 210$

8690 B.C.

$9550 \pm 130$ 7600 в.c.

Tx-895. La Calsada C-43: U6, L12-13

General Comment (C.R.N.): dates provide good series, although some mixing within units is evident, and Unit 3 and 4 dates overlap. Estimated times of units are: Unit 1-2, A.D. 900 to historic; Unit 3, 2500 B.c. to after 1200 в.c. (by comparison with Cueva de la Zona de Derrumbes 
where earliest Tortugas points are post-1200 B.c.; see Tx-147, Radiocarbon, 1965 , v. 7, p. 312); Unit 4, 4000 B.c. to 2500 в.c.; Unit 5, 7500 B.c. to after 5000 B.c.; Unit 6 , before 8700 в.c. to 7500 в.c.

\section{REFERENCES}

Ambler, J. R., 1967, Three prehistoric sites near Cedar Bayou, Galveston Bay area: State Bldg. Comm., Archaeol. Program, rept. no. 8, Austin, Texas.

Bender, M. M., 1968, Mass spectrometric studies of carbon 13 variations in corn and other grasses: Radiocarbon, v. 10, p. 468-472.

Brannon, H. R., Jr., et ai., 1957, Humble Oil Company radiocarbon dates I: Science, v. 125 , p. $147-150$.

Broecker, W. S., Kulp, J. L., and Tucek, C. S., 1956, Lamont natural radiocarbon mcasurements III: Science, v. 124, p. 154-165.

Crane, H. R. and Griflin, J. B., 1958, University of Michigan radiocarbon dates II: Science, v. 127, p. 1098-1105.

Fisk, H. N., 1959, Padre Island and Laguna Madre Flats, Coastal south Texas: 2nd Coastal Geog. Conf., Coastal Studies Inst., Louisiana State Univ., U.S. Office of Naval Research, Washington, p. 103-152.

Ford, J. A. and Webb, C. H., 1956, Poverty Point: Amer. Mus. Nat. Hist., Anthrop. Papers, v. 46, pt. 1 .

Frishman, S. A., 1969, Geochemistry of Oolites, Baffin Bay, Texas: M. S. thesis, Dept. Geol. Sciences, Univ. of Texas, Austin.

Greer, J. W., 1968, Notes on excavated ring midden sites, 1963-1968: Texas Archaeol. Soc. Bull., v. 38, p. 39-44.

Haynes, C. V., 1968, Radiocarbon: analysis of inorganic carbon of fossil bone and enamel: Science, v. 161, p. 687-688.

Jelks, E. B., 1962, The Kyle site: Dept. of Anthropol., Univ. of Texas, Archaeol. ser. 5.

Kidder, A. V., 1932, The artifacts of Pecos: Phillips Acad. southwestern expedition, Paper 6.

Libby, W. F., 1955, Radiocarbon Dating, 2nd ed. Univ. of Chicago Press, ix, 175 p.

Milliman, J. D. and Emery, K. O., 1968, Sea levels during the past 35,000 years: Science, v. 162 , p. $1121-1123$.

Newell, H. P. and Krieger, A. D., 1949, The George C. Davis site, Cherokee County, Texas: Soc. Amer. Archaeol., mem. 5.

Parsons, M. L. 1967, Archacological investigations in Crosby and Dickens Counties, Texas during the winter, 1966-67: State Bldg. Comm., Archaeol. Program, rept. no. 7, Austin, Texas.

Scholl, D. W., Craighead, F. C., Sr., and Stuiver, M., 1969, Florida submergence curve revised: its relation to coastal sedimentation rates: Science, v. 163, p. 562-564.

Shepard, F. P., 1963, Thirty-five thousand years of sea level, in: Clements, T. (ed.), Essays in marine geology in honor of K. O. Emery, p. 1-10, Los Angeles, Univ. of S. Calif. Press.

Skinner, S. A., Harris, R. K., and Anderson, K. M., 1969, Archaeological investigations at the Sam Kaufman site, Red River County, Texas: Southern Methodist Univ., Contr. in Anthropol., no. 5.

Suhm, Dee Ann, 1957, Excavations at the Smith Rockshelter, Travis County, Texas: Texas Jour. Sci., v. 9, p. 26-58.

Tamers, M. A., 1970, Validity of radiocarbon dates on terrestrial snail shells: Amer. Antiquity, v. 35, p. 94-100.

Webb, C. H., 1968, The extent and content of Poverty Point culture: Amer. Antiquity, v. 33, p. $297-321$. 